\title{
Organizational Intelligence and Employee Performance: The Mediating Role of Distributive Justice
}

\author{
Muhammad Qasim Shabbir ${ }^{*}$, Waleed Khalid², Muhammad Haider Ali ${ }^{3}$ \\ ${ }^{1}$ IQRA University, Islamabad Pakistan \\ ${ }^{2}$ National University of Modern Languages, Islamabad Pakistan \\ ${ }^{3}$ Comsats Institute of Information Technology, Islamabad Pakistan \\ *jarral.rajput@gmail.com, rajawaleedkhalid@yahoo.com, Muhammad.haider.engr@gmail.com
}

\begin{abstract}
A well thriving education system, initiate and promotes innovation along research, is a key to the performance, productivity and sustainability in the august world class universities, colleges and schools. Globalization and digital revolution are creating new strategic competition and advancement as, a result innovative knowledge and learning's are driving our economic system. Both public and private organizations are forced to adopt these innovative and technical reforms in order to survive in a competitive environment, which can be possible through spiraling education system by research and innovative techniques. This study intends to investigate the mediating effects of distributive justice on relationship between organizational intelligence and employee performance in education sector. Based on a sample of 113 employees and using structural equation modeling approach, the organizational intelligence is found to have positive effects on distributive justice. The findings of the study suggest that the effects of organizational intelligence on employee performance are fully mediated by distributive justice. This study provides a strapping foundation for all educational institutes to analyze whether they are implementing strategic management practices or not. Systematic and assertive implementation of these practices will not only uplift the quality and standards of educational institutions but also essential for better performance of every industry.
\end{abstract}

Keywords: Organizational Intelligence, Distributive Justice, Employee Performance, Educational Institutions

\section{Introduction}

Globalization and digital revolution has created a demand for use of innovative techniques and new practices in education sector. Educational institutions are now heavily dependent on mental resources and human capitals for knowledge dispersion (Gill, 2009) The cost of providing the quality of services and education has gone up due to the advancement in technologies, use of high resources, learning and adoption of new techniques with better teaching methodologies. The vigorous increase in the number of institutions equipped with these competitive advantages in education sector has led to an intense competition. In modern times one of the greatest management challenges is how to create a new generation of intelligent Organizations. Organizational intelligence is gained by specific vision, knowledge learning, morale of employees and pressure of performance(Kesti, Syvajarvi, Stenvall, \& Rivera, 2011).In education sector, being knowledgebased organizations, universities, colleges and other such organizations must be a pioneer for achieving, producing and sharing organizational intelligence. Now a day's knowledge is consider as the back bone of global economy and knowledge management plays very significant role in achievement of organizational success at every level, therefore knowledge management is considered as foremost constituent of structure and process of any training organization (Raj Adhikari, 2010).Our capability to give challenge or stay alive in the global economic system is strictly based on our dedication and attitude to develop our knowledgeable human capital. This can be only possible by constructing of constant learning process and knowledge management in term of organizational intelligence within the government institutions and all other organizations in order to construct innovative culture. This Innovation is related with enhancement in our productivity and competitive performance at national level and the dynamic innovation systems engage interaction among a number of different components in our civilization which is based on the public and private sector educational and research institutions (Mikulecký, Lodhi, \& Mastorakis, 2009).The literature on employees performance in educational sector of Azad Kashmir \&Pakistan remains scarce .So, this study is designed to investigate the organizational intelligence practices which are imperative to boost the employee's performance in educational sector of Azad Kashmir and Pakistan. Moreover, this study underwrites to the prevailing body of knowledge by investigating the mediating role of distributive justice on the relationship between organizational intelligence and employee performance. 


\section{Theoretical Framework}

This section presents the theoretical foundations for the three constructs of the study, namely, Organizational intelligence, distributive justice and employee productivity.

Employee Performance: Employees' performance is precise definition towards accomplishment of organizational goals ,So in order to satisfy the needs of the employees ,the enterprise undertake the duties and responsibilities of such workforce who effort more and get what they want by giving more importance to their working(Yilmaz \& Ergun, 2008). Therefore, enterprise develops their careers and working life by introducing training programs, promote their ranks and rendered more compensations and extra bonus salaries for their best goals oriented work, It is because enterprise with these skilled human resource will achieve their business goals more effectively and efficiently(Bourlakis, Maglaras, Aktas, Gallear, \& Fotopoulos, 2014).The three main factors that effects performance of employee are categories as , organizational, personal and environmental factors (Gümüștekin \& Öztemiz, 2005).Employee Performance is based on the result of the output at the end of a certain time; this result is the degree of accomplishment of business objectives or goals. So, therefore performance is the result of all efforts use to attain business objectives (Gümüştekin \& Öztemiz, 2005)

Organizational Intelligence: Organizational intelligence is new concept in the course of texts and management, its background dated in 1990s and its roots can be searched in theories of organizational learning and knowledge management. Initially, Matsuda coined organizational intelligence and observed organizational intelligence as combination of human and machine intelligence. The model was defined by him explains the process of human knowledge and science based on machine for sorting out organizational problem (Kim, Suh, \& Hwang, 2003).The ability to learn, reason, and understand is known as intelligence (Kesti et al., 2011). Whereas Organizational intelligence is defined as the quantitative evaluation of usefulness in distribution of information, decision making process and implementation by an organization (Yaghoubi, Gholami, \& Armesh, 2012).The ability of an organization to generate knowledge and utilize it by strategically adapting it on situation or marketplace is organization intelligence. The study of organizational intelligence determine the intellectual competence of whole organizations, as like we use to calculate the intelligence of people by using I.Q. Simply, It is just similar to I.Q but applied at an organizational level abbreviated as O.I.Q. General Motors has an O.I.Q. of 85, I.B.M. is rated at 105 and Microsoft is having 120(Halal, 1997). The evaluation of organizational intelligence went ahead of the cognitive point of views as organizational intelligence extends due to the day-to-day actions of the organization. So its evaluation based on social, behavioral, emotional and cognitive dimension and in this way, organizational intelligence is a multifaceted and multidimensional concept comprised of the recursive interaction of cognitive, emotional and behavioral potential of organization (Ali \& Ahmad, 2006)

Distributive Justice: Immoral decision making by employee in organization will lead to a lofty cost for person and organization collectively. So managers and accountable people should expand additional effort to devise an appraisal system for performance which allows employee to participation at some stage in the planning. The basic and vital cause should be to raise the insight of justice as what employees supposed to be fair and justice based on their personal experience and upon authorized judgment concerning appropriate ways to attain distributive results and to deal others with justice (Cropanzano, Ambrose, Greenberg, \& Cropanzano, 2001) .Theory of distributive justice has its roots in old theories like equity theory (Cook \& Parcel, 1977) and social exchange theory(Cook \& Parcel, 1977), As per these theories, employees use to assess justice in the social exchange association with their organization according to the ratio between rewards and labors spent by them at their work. Job efforts are based on widespread induction of resources like training and development, skill development, seniority level, time consumption , energy and efforts , intelligence with experience which labor required to perform work properly whereas, Job rewards indicates to compensations and resources which employees obtain by the organization in return which includes wages, supportive, working equipment, decision freedom, number of vacations, self-esteem, social status, social position. Employee's observation from fair attitude in work has been leaded to point our three different dimensions of justice in the organization i.e. Distributive justice, procedural justice and interactional justice (Cropanzano et al., 2001). 
Research Model and Hypothesis: This section presents the conceptual framework and hypothesis of the study. It also highlights the relationships between the variables in the study. The study argues that Distributive Justice mediates the relationship between Organizational Intelligence and Employees Performance.

Figure 1: Showing Direct Relationship

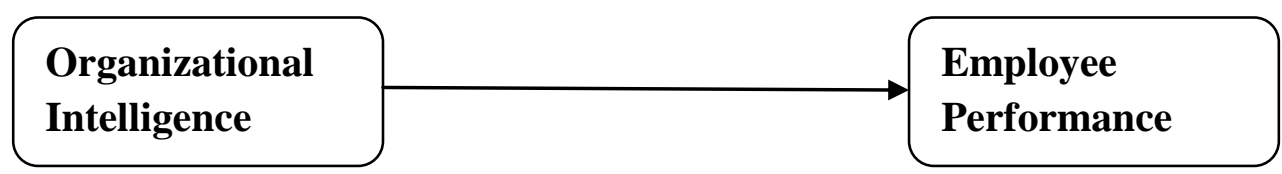

Figure 2: Showing Mediating Relationship

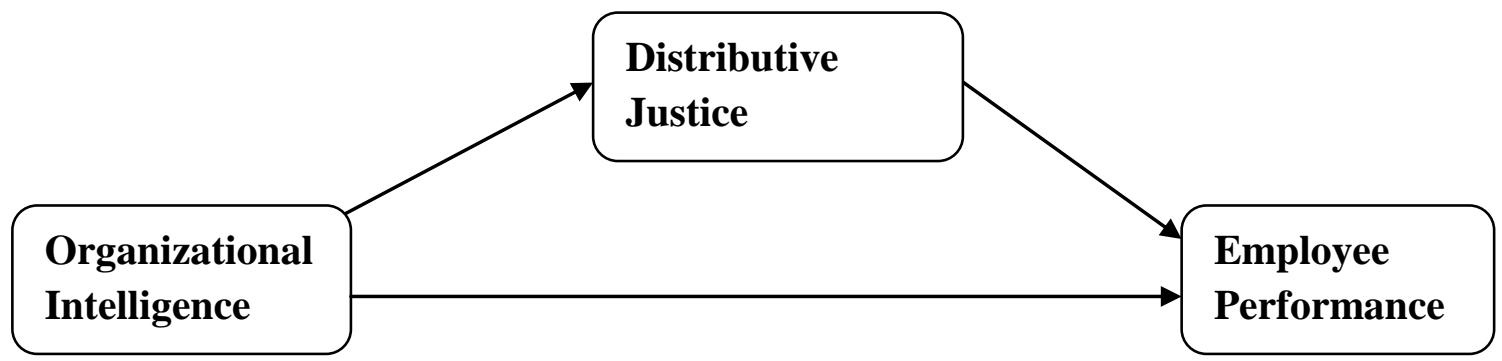

The figure 1indicates direct relationship of organizational intelligence and employee performance, whereas, figure 2 indicates employee's performance as dependent variable, organizational intelligence as independent variables and distributive justice as mediating variable.

Organizational Intelligence and Employee Performance: Organizational intelligence is the joint management of both public policy and business intelligence implicit and explicit knowledge results in the creation of the organizational Intelligence(Kesti et al., 2011).In a study it is found a positive link between organizational intelligence and performance of employees, where organizational intelligence is gained by specific vision, knowledge learning, morale of employees and pressure of performance(Kesti et al., 2011). In a study it is found positive relationship at significant level between the employees performance in term of productivity and organization intelligence. The more employees feel attached and satisfy with their workplace, more productively they perform (Müller \& de Castilho Jr., 2015). Now days, organizations are considering to strengthen their keenness to survive by looking into new vision. Believing that organization intelligent help to solve many issues by creating favorable atmosphere for employees, those organizations which believe in abilities and utilize their strategic actions plan to achieve goals is major factor to developed organization intelligence and employee performance in term of productivity (Karimi \& Akbari, 2014).In a study it was found a positive relation between organization intelligence and employee performance by creating a healthy environment. If organizations put focus on its strategic actions plan to adapt competitive environment there will be more focus of employees to enhance productivity and satisfaction of its employees(Al-khatani \& Khan, 2013).In organization sectors where employees display organization intelligence have greater effect on their performance on job , so educational institute select their productive employees to adapt administrative organization intelligence (Ahmadi, Nami, \& Barvarz, 2014).

H1: Organizational Intelligence positively influence Employees Performance

Organizational Intelligence and Distributive Justice: Distributive justice is known to be related to the organizational activities and environment, it relates to the job position as well as job rotation, its basic aim to treat the employee Fairly(Yilmaz \& Tasdan, 2009). It reflects the perception in employees for equality and it brings transparency in the organization for employee fulfillment(Mehrabi, 2012).To develop personal as well as creative awareness of employees it is very mandatory to create creative process engagement among employees and management. If there is positive atmosphere and interactional justice with excellence knowledge and logical thoughts there is positive link between organizational intelligence and distributive justice in organization(Delshad, Kolouie, \& Ali, 2016).If distributive justice is practiced by members in 
organization, then members will produce more positive outcome. Where upper management could enhance and motivate to promote organizational intelligence, which result to fulfill not only individual level need but also assist enhance organizational efficiency and productivity and organization should manage their human resource effectively (Delshad \& Nejadheidar, 2016).Previous studies investigating organizational effectiveness mostly refer to the organizational intelligence as one of the main and operative variables on efficiency(Aghaei, Mirzamohammadi, \& Shirkavand, 2013).Significant association is considered in term of organizational intelligence and distributive justice and organizational performance; likewise, among the research variables, organizational intelligence had highest correlational coefficient to organizational effectiveness (Aghaei et al., 2013).

H2: Organizational Intelligence positively influence on Distributive Justice.

Distributive Justice and Employee Performance: Distributive justice is the sign of the extent to which employees are treated justly by the organization and its authorities(Janssen, Lam, \& Huang, 2010).In addition there are different views for distributive justice like personal out comes, job satisfaction and organizational out comes, it include all reward system, and job satisfaction, power and authority(Eslami \& Gharakhani, 2012).In the modern age of globalization; where every organization is putting effort to maintain their employees, distributive justice and performance of employees are more considering parts. However, only those organizations are successful where all these factors are providing to employees in competitive age (Imran, Majeed, \& Ayub, 2015). Distributive justice is the symbol of profit in the organization because it holds motivation and performance among the employees and it also provides help for managers to bring fair practice in the organization. It is directly proportional to the organizational efficiency as well (Jandaghi, Alimadadi, Fard, \& Golverdi, 2012). Janssen et al. (2010) had supported one of the most extensively established proposition in previous studies about justice that distributive justice has very significant influence on behavior regarding particular outcomes at work for example i.e. employee performance. Organization also performs a vital role to enhance performance of employees in term of productivity by removing their turn over attitude. Al Afari \& Elanain (2014)Distributive Justice also influences on the decision making and also it effects the employee performance, if it is the wide spread element in the organization. It leads to decrease performance of Employee if unfair and illegal practices held in the organization, which influence negatively on the perception of employees (Ismail, Abdul-Majid, \& Joarder, 2014).

H3: Distributive justice practices positively influence Employees Performance

The Mediating Role of Distributive Justice: Organizational intelligence is based on collection of information, experience and perceives new problems (Simic, 2015).Distributive justice helps to establish formal constant instrument and which enhance link and mediate between organization intelligence and productivity of employees within the organization, portentous decrease or the total eradication of intentions to emotionally or physically extract from work (Douglas, 2015). Moreover, Vilar \& Pablo (2013)underline that human resource management aspects "distributive justice and pay for performance" are important to consider to improve employee's performance in the organization. In the modern age of globalization; where every organization is putting effort to maintain their employees, distributive justice and performance of employees are more considering parts, mediating relationship of knowledge management between organization learning and employee performance is approved. However, only those organizations are successful where all these factors are providing to employees in competitive age (Imran et al., 2015). If distributive justice is providing to employees then an organization can gain an employee's productivity by creating knowledge and focus on long term objectives to adapt environment, because if work load is increased of employees within organization then it last bad effect towards productivity of employees and organization learning (Iqbal, 2013). Moreover, Al Afari \& Elanain (2014) state that justice in Organization also performs a vital role to enhance performance of employees by removing their turn over attitude. Practicing more organizational intelligence in term of organizational learning could increase more creativity of their employees, by giving employees autonomy and creative process engagement.

H4: Distributive Justice mediates the relationship between organizational intelligence and employee's performance 


\section{Methodology}

Data Collection and Sample: To collect the data from Pakistani nationals a personally administrated questionnaire was distributed in the state of Azad Kashmir and Punjab province of Pakistan from the employees of educational institutions. A rational attempt was made to randomize the sampling process by selecting random institutions and different locations for the data collection. A total of 113 employees responded to this survey. Some respondents refused to participate to this study due to personal inconvenience. The source of non-sampling error cannot be controlled as there is no such information available about them; the survey analysis was used because it is the most efficient methodology to gather data from huge populated segment (Bradley \& Sparks, 2002).

Measurement: There were three constructs in the study, organizational intelligence, distributive justice and employee performance. All the constructs were measured with the statements adapted from previous studies by(Glatzeder, Goel, \& von Müller, 2010),(Niehoff \& Moorman, 1993)and (Wallace \& De Chernatony, 2009). All the items in questionnaire which are selected from the previous researcher's work are modified according to need for present study A 5-point Likert type scale ranging from (1) strongly disagree to (5) strongly Agree.

\section{Results}

Descriptive Results: As noted, all the constructs were assesses using 5-point Likert scales, before starting the analysis reliability of data was checked by using SPSS-21. The reliability analysis is comprised of "Cronbach, s Alpha" that gives an accurate idea about internal data consistency(Table 2),(Smith, Murphy, \& Mahoney, 2003) states that the Cronbach Alpha is best method to analyze the internal consistency of data. Table 1 shows descriptive Mean, standard deviation and Pearson Correlation. As depicted in Table 1, the means range from 3.8584 to 3.4292 .The correlation illustrate the direction and strength of linear relationship between two variable, here correlation analysis was employed to access the possible association between organizational intelligence, distributive justice and employee performance. The results of analysis show the significant correlations among all variables.

Table 1: Results of Correlation Analysis.

\begin{tabular}{|c|c|c|c|c|c|}
\hline & Mean & $\begin{array}{l}\text { Std. } \\
\text { Deviation }\end{array}$ & $\begin{array}{l}\text { Organizational } \\
\text { Intelligence }\end{array}$ & $\begin{array}{l}\text { Distributive } \\
\text { Justice }\end{array}$ & $\begin{array}{l}\text { Employee } \\
\text { Performance } \\
\end{array}$ \\
\hline $\begin{array}{l}\text { Organization } \\
\text { Intelligence }\end{array}$ & 3.4292 & 67693 & 1 & $\begin{array}{l}.215^{*} \\
.022\end{array}$ & $\begin{array}{l}.227^{*} \\
.015\end{array}$ \\
\hline $\begin{array}{l}\text { Distributive } \\
\text { justice }\end{array}$ & 3.4159 & .97720 & $\begin{array}{l}.215^{*} \\
.022\end{array}$ & 1 & $\begin{array}{l}.256^{* *} \\
.006\end{array}$ \\
\hline $\begin{array}{l}\text { Employee } \\
\text { Performance }\end{array}$ & 3.8584 & .73706 & $\begin{array}{l}.227 * \\
.015\end{array}$ & $\begin{array}{l}.256^{* *} \\
.006\end{array}$ & 1 \\
\hline
\end{tabular}

* Correlation is significant at the 0.05 level (2-tailed)

** Correlation is significant at the 0.01 level (2-tailed).

Measurement Model: Measurement model is drawn to carry out the Confirmatory Factor Analysis and Maximum Likelihood Method is used to calculate the parameters. Confirmatory Factor Analysis is done because established measurement scale is used in this study and reliability of the instrument describes how well the thirteen items had calculated the three constructs. CFA was performed for each of three variables on the measurement model using AMOS-23. The CFI of every construct is between 0.93 to 1.00 shows good fit, thus signifies evidence of uni-dimensionality(Aagja \& Garg, 2010). The measurement properties of the five scales indicate that the factor loadings are high and statistically significant $(p<0.05)$.These results satisfy the criteria for convergent validity and are actually good indicators of CFA (Salzberger, Sinkovics, \& Schlegelmilch, 1999).To test the construct reliability; squared multiple correlations $\left(R^{2}\right)$ for every item and reliability is used in this study. The $\left(\mathrm{R}^{2}\right)$ for every item ranges between 0.05 to 0.69 , thus shows good reliability (Holmes-Smith, 2002), as it shows variance in variable provided by latent construct. Therefore, all 
the constructs shows good fit, as well as are uni-dimensional. Moreover, Cronbach alpha values were calculated to measure reliability of the constructs and values lie between 0.70 to 0.80 are showing good indication of internal consistency and reliability , Cronbach's alpha ranges from 0 to 1.00, with values close to 1.00 indicating high consistency(Wells \& Wollack, 2003).

Table 2: Results of Confirmatory Factor Analysis (CFA) Model.

\begin{tabular}{|c|c|c|c|c|c|c|}
\hline $\begin{array}{l}\text { Latent Construct/ } \\
\text { Factors }\end{array}$ & $\begin{array}{l}\text { Items } \\
\text { Indicators }\end{array}$ & l & $\begin{array}{l}\text { Factors } \\
\text { Loadings }\end{array}$ & CFI & $\left(\mathbf{R}^{2}\right)$ & $\begin{array}{l}\text { Reliability } \\
\text { Cronbach's } \\
\text { alpha }\end{array}$ \\
\hline Organizational & OI1 & & 0.37 & 0.93 & 0.13 & 0.71 \\
\hline \multirow[t]{5}{*}{ Intelligence } & $\mathrm{OI} 2$ & & 0.24 & & 0.05 & \\
\hline & OI3 & & 0.83 & & 0.68 & \\
\hline & OI4 & & 0.83 & & 0.69 & \\
\hline & OI5 & & 0.50 & & 0.25 & \\
\hline & $0 \mathrm{OI}$ & & 0.45 & & 0.20 & \\
\hline \multirow[t]{4}{*}{ Distributive Justice } & DJ1 & & 0.64 & 1.00 & 0.41 & 0.80 \\
\hline & DJ2 & & 0.79 & & 0.62 & \\
\hline & DJ3 & & 0.78 & & 0.61 & \\
\hline & DJ4 & & 0.62 & & 0.38 & \\
\hline \multirow[t]{3}{*}{ Employee Performance } & EP1 & & 0.79 & 1.00 & 0.37 & \\
\hline & EP2 & & 0.60 & & 0.35 & 0.70 \\
\hline & EP3 & & 0.61 & & 0.61 & \\
\hline
\end{tabular}

Figure 3: Showing Mediating Effect

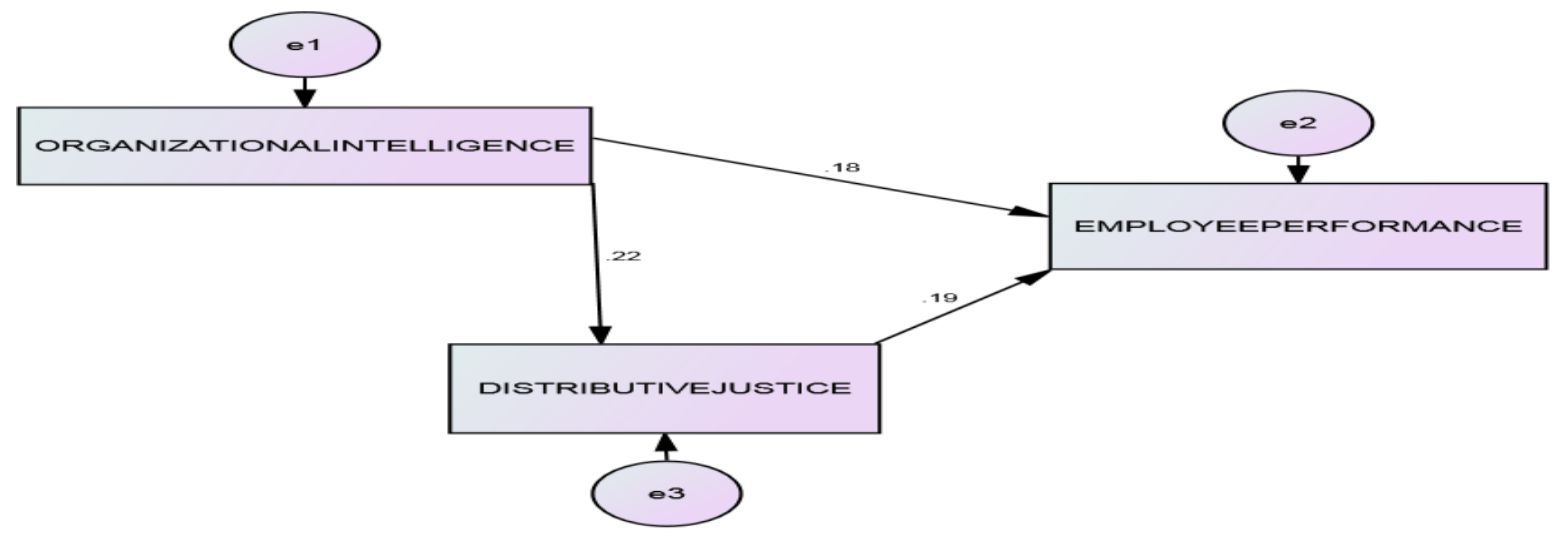

Structural Equation Model: The figure 3shows the mediating effect among the variable, structural equation model helps to measures the impact and potential of organizational intelligence and its relation to distributive justice. It further reveals the importance and role of independent variable for distributive justice and its effects on employee performance. The results of above hypothesis test based on estimates from standardized regression weights of the relationship between constructs including organizational intelligence, distributive justice and employee performance are shown in Table 3 and figure 3 . The Beta value is 
0.22between organizational intelligence and distributive justice and the relationship is evident from the analysis that if there is one degree change in between organizational intelligence there would be $0.22 \%$ change in distributive justice. Also the relationship between organizational intelligence and employee performance has Beta value 0.18 relationships between distributive justice and employee performance shows the Beta value 0.19 whereas, relationship between organizational intelligence and employee performance has Beta value 0.18. These results support our hypothesis about positive and significant mediating effect of distributive justice on relationship between organizational intelligence and employee performance.

Table 3: Hypothesis Testing based on Standardized \& Unstandardized Regression Weights

\begin{tabular}{|c|c|c|c|c|c|c|c|}
\hline & & & Estimate & S.E. & C.R. & $\mathbf{P}$ & Decision \\
\hline Distributive Justice & $<---$ & $\begin{array}{l}\text { Organizational } \\
\text { Intelligence }\end{array}$ & 0.22 & 0.122 & 2.435 & 0.01 & Accepted \\
\hline $\begin{array}{l}\text { Employee } \\
\text { Performance }\end{array}$ & $<---$ & $\begin{array}{l}\text { Organizational } \\
\text { Intelligence }\end{array}$ & 0.18 & 0.101 & 1.995 & 0.04 & Accepted \\
\hline $\begin{array}{l}\text { Employee } \\
\text { Performance }\end{array}$ & $<--$ & Distributive Justice & 0.19 & 0.076 & 2.035 & 0.04 & Accepted \\
\hline
\end{tabular}

Discussion: The findings of study, support theory of Performance (ToP) that also suggests that developing performance is continues journey and location of journey is reflected by performance level. Whereas Performance is collective effort of individual or by group of people(Elger, 2007).So there is need to put more focus on the knowledge and learning factors, that support the positive behavior toward employee performance. The research findings are consistent with prior literature findings. In a study it is found a positive link between organizational intelligence and performance of employees, where organizational intelligence is gained by specific vision, knowledge learning, morale of employees and pressure of performance (Kesti et al., 2011). Also, Janssen et al. (2010) had supported one of the most extensively established proposition in previous studies about justice that distributive justice has very significant influence on behavior regarding particular outcomes at work for example i.e. employee performance. It is concluded that all the hypotheses were supported and consistent results are found in this study with the prior research findings. We have found that the distributive justice mediates the relationship among organizational intelligence and employee performance and have significant and positive impact on their relationship. Distributive justice belongs to assessment of equity in both rewards and benefits, taken from organization for the return of making good efforts for the organization. Distributive justice helps to establish formal constant instrument and which enhance link and mediate between organization intelligence and performance of employees as productivity within the organization. ; Portentous decrease or the total eradication of intentions to emotionally or physically extract from work(Cropanzana, Bowen, \& Gilliland, 2007).Our population sample was taken from educational institutions and previous literature supports our findings that teaching organization convert itself for the better management and empowering the people to learn and develop also use of technology to maximize the learning and production capability (Marquardt, 1996). Moreover, if there is distributive justice prevailing in organization it will results in motivation for employees and raise their efficiency .It also results in lower absenteeism and turnover rate with higher productive attitude among employees (Colquitt et al., 2001). So, if there is fairness and justice prevailing in behavior, attitude, resource and rewards allocation of managers in organization, it will influence significantly to employee performance (Greenberg, 1993). Also, One of the extensively established and prevailing proposition in organizational justice research is that distributive justice have very significant influence on specific out comes by employees at their in terms of their job satisfaction, and performance (Melkonian, Monin, Rouzies, Noorderaven, \& Timmers, 2006).

\section{Conclusion}

This contemporary study underwrites to the emergent body of literature on employee performance and organizational intelligence in two ways. Primarily depiction on past research, a parsimonious model of organizational intelligence is developed and tested for educational institutions. This study suggests that one of the key determinants of employee performance is organizational intelligence .Thus, by investigating the 
effect of organizational intelligence on employee performance, our study drawn-out the symbolic meaning of the existing models of employee performance e.g. (Bourlakis et al., 2014). The study suggests that organizational intelligence have a significant effect on employee performance. The contemporary research delineates how unfathomable and meaningful association can be established between employees and their performance through symbolic organizational intelligence. Thus, the study validates the verdicts of earlier studies by(Kesti et al., 2011)and most recently that of(Ahmadi et al., 2014). Furthermore, this study underwrites to the existing body of knowledge by investigate the impact of distributive justice on relationship between of organizational intelligence and employee performance. The population of this research was educational institutions of Azad Kashmir and Punjab in Pakistan. This pragmatic research is the first to inspect the impact of distributive justice on the relationship between organizational intelligence and employee performance in educational sector. The study finds that distributives justice fully mediates the effects of organizational intelligence on employee performance and therefore supports the importance of organizational intelligence for employee performance e.g.(Kesti et al., 2011).

Recommendations: Educational sector in Azad Kashmir has grown over the period of time and now as compare to any other region in Pakistan it has higher literacy rate of 72 percent, whereas according to a study, Punjab is with literacy rate of 61.7percent(Rehman, Jingdong, \& Hussain, 2016) .On the other hand Studies indicates that the state of Azad Kashmir is failing to deliver the quality of education, where two among five students are not properly able to read very simple story in Urdu and sixty percent of students are not able to solve simple mathematics. So government should take steps to be a facilitator of technological Capabilities in all organizations and it can only be possible if we enhance our educational system and apply research and development in organizations while creating effectual linkages between universities and industries. Systematic and assertive implementation of organizational intelligence and distributive justice practices will not only uplift the quality and standards of educational institutions but is essential for the better performance of every industry.

\section{References}

Aagja, J. P. \& Garg, R. (2010). Measuring perceived service quality for public hospitals (PubHosQual) in the Indian context. International Journal of Pharmaceutical and Healthcare Marketing, 4(1), 60-83.

Aghaei, N., Mirzamohammadi, S. \& Shirkavand, S. (2013). Inter-Market Analysis: Assessing Impact Level of Fluctuation in other Financial Markets on Stock Market Fluctuations. Asian Journal of Research in Banking and Finance, 3(11), 110.

Ahmadi, S., Nami, Y. \& Barvarz, R. (2014). The Relationship between spirituality in the workplace and organizational citizenship behavior. Procedia-Social and Behavioral Sciences, 114, 262-264.

Al-khatani, N. S. \& Khan, A. N. (2013). Human resource development practices in telecom sector in Saudi Arabia: an empirical presentation. World applied science journal, 3, 1567-1578.

Al Afari, T. S. \& Elanain, H. M. A. (2014). Procedural and distributive justice as mediators of the relationship between interactional justice and work outcomes: An empirical study of the UAE public health care sector. Journal of Applied Business Research, 30(4), 1091.

Ali, H. M. \& Ahmad, N. H. (2006). Knowledge management in Malaysian banks: a new paradigm. Journal of Knowledge Management Practice, 7(3), 1-13.

Bourlakis, M., Maglaras, G., Aktas, E., Gallear, D. \& Fotopoulos, C. (2014). Firm size and sustainable performance in food supply chains: Insights from Greek SMEs. International Journal of Production Economics, 152, 112-130.

Bradley, G. \& Sparks, B. A. (2002). Fair process revisited: Differential effects of interactional and procedural justice in the presence of social comparison information. Journal of experimental social psychology, 38(6), 545-555.

Cook, K. S. \& Parcel, T. L. (1977). Equity theory: Directions for future research. Sociological Inquiry, 47(2), 7588.

Cropanzana, R., Bowen, D. E. \& Gilliland, S. W. (2007). The management of organizational justice. The Academy of Management Perspectives, 2, 34-48.

Cropanzano, R., Ambrose, M. L., Greenberg, J. \& Cropanzano, R. (2001). Procedural and distributive justice are more similar than you think: A monistic perspective and a research agenda. Advances in organizational justice, 119, 151. 
Delshad, A., Kolouie, S. R. \& Ali, S. A. (2016). The effect of intellectual intelligence on employee perceptions of organizational justice in Qeshm Free Zone. Human Resource Management, 3(1), 26-35.

Delshad, A. \& Nejadheidar, A. (2016). The Assessment of the Effect of Personality Factors in the Improvement and Organizational Change (Case Study: Employees of Social Security Organization). European Online Journal of Natural and Social Sciences: Proceedings, $4(1$ (s)), 2180-2189.

Douglas, V. T. (2015). Administration of Justice and Internal Party Democracy: a Study of 2007 People's Democratic Party Gubernatorial Primary Election in Rivers State.

Elger, D. (2007). Theory of performance. Faculty guidebook: A comprehensive tool for improving faculty performance, 1, 19-22.

Eslami, J. \& Gharakhani, D. (2012). Organizational commitment and job satisfaction. ARPN Journal of Science and Technology, 2(2), 85-91.

Gill, A. (2009). Knowledge management initiatives at a small university. International Journal of Educational Management, 23(7), 604-616.

Glatzeder, B., Goel, V. \& Von Müller, A. (2010). Towards a theory of thinking: Building blocks for a conceptual framework: Springer Science \& Business Media.

Gümüştekin, G. E. \& Öztemiz, A. B. (2005). Örgütlerde stresin verimlilik ve performansla etkileşimi. Çukurova Üniversitesi Sosyal Bilimler Enstitüsü Dergisi, 14(1).

Halal, W. E. (1997). Organizational Intelligence: What is it. And how can manager use it? Retrieved, 2007.

Holmes-Smith, P. (2002). Applied structural equation modeling. Feburay, Canbera.

Imran, R., Majeed, M. \& Ayub, A. (2015). Impact of organizational justice, job security and job satisfaction on organizational productivity. Journal of Economics, Business and Management, 3(9), 840-845.

Iqbal, K. (2013). Determinants of Organizational Justice and its impact on Job Satisfaction. A Pakistan Base Survey. International review of management and business research, 2(1), 48.

Ismail, A. I., Abdul-Majid, A. H. \& Joarder, M. H. R. (2014). Mediating Role of Distributive Justice in the Relationship between Career Incentives and Employee Performance. Paper presented at the International Conference on Business, Marketing and Management, Hong Kong.

Jandaghi, G., Alimadadi, A., Fard, S. M. H. \& Golverdi, M. (2012). Relationship between organizational justice and staff happiness in the institutes of standard \& industrial research of Qom province and jihad agricultural management in Qom city. Human Resource Management, 43, 6618-6626.

Janssen, O., Lam, C. K. \& Huang, X. (2010). Emotional exhaustion and job performance: The moderating roles of distributive justice and positive affect. Journal of Organizational Behavior, 31(6), 787-809.

Karimi, F. \& Akbari, M. (2014). The mediation role of organizational intelligence in relationship between organizational learning capability and organizational citizenship behavior.

Kesti, M., Syvajarvi, A., Stenvall, J. \& Rivera, M. (2011). Human capital scenario analysis as an organizational intelligence tool for performance management. Problems and Perspectives in Management, 9(1), 4648.

Kim, S., Suh, E. \& Hwang, H. (2003). Building the knowledge map: an industrial case study. Journal of knowledge management, 7(2), 34-45.

Marquardt, M. J. (1996). Building the learning organization: McGraw-Hill Companies New York, NY.

Mehrabi, J. (2012). Application of Six-Sigma in educational quality management. Procedia-Social and Behavioral Sciences, 47, 1358-1362.

Melkonian, T., Monin, P., Rouzies, A., Noorderaven, N. \& Timmers, A. (2006). Justice, or exemplarity? Theoretical bases and empirical contributions to post-merger performance. Paper presented at the Academy of Management Conference, Atlanta, GA.

Mikulecký, P., Lodhi, M. S. \& Mastorakis, N. E. (2009). Knowledge management at educational institutions: case of Pakistan. Paper presented at the 10th proceedings of the WSEAS Int. Conference on mathematics and computers in business and economics.

Müller, R. \& de Castilho, J. (2015). Newton Correa. Inteligência Organizacional: Perspectivas No Setor Hospitalar Na Cidade De Curitiba, PR.

Niehoff, B. P. \& Moorman, R. H. (1993). Justice as a mediator of the relationship between methods of monitoring and organizational citizenship behavior. Academy of Management journal, 36(3), 527556.

Raj Adhikari, D. (2010). Knowledge management in academic institutions. International Journal of Educational Management, 24(2), 94-104. 
Rehman, A., Jingdong, L. \& Hussain, I. (2016). Literacy Rate in Pakistan, Province Wise and its Impact on Economy. ANDAMIOS, 13(1).

Salzberger, T., Sinkovics, R. R. \& Schlegelmilch, B. B. (1999). Data equivalence in cross-cultural research: A comparison of classical test theory and latent trait theory based approaches. Australasian Marketing Journal (AMJ), 7(2), 23-38.

Simic, O. (2015). Springer Series in Transitional Justice.

Smith, P. J., Murphy, K. L. \& Mahoney, S. E. (2003). Towards identifying factors underlying readiness for online learning: An exploratory study. Distance education, 24(1), 57-67.

Vilar, P. \& Pablo, S. (2013). Relationships between the'Hard'Variables of Human Resource Management and Job Satisfaction. International Journal of Business and Social Science, 4(1).

Wallace, E. \& De Chernatony, L. (2009). Service employee performance: its components and antecedents. Journal of Relationship Marketing, 8(2), 82-102.

Wells, C. S. \& Wollack, J. A. (2003). An instructor's guide to understanding test reliability. Testing \& Evaluation Services. University of Wisconsin.

Yaghoubi, N. M., Gholami, S. \& Armesh, H. (2012). The relationship between strategic processes of knowledge management and organizational intelligence. African Journal of Business Management, 6(7), 2626.

Yilmaz, C. \& Ergun, E. (2008). Organizational culture and firm effectiveness: An examination of relative effects of culture traits and the balanced culture hypothesis in an emerging economy. Journal of world business, 43(3), 290-306.

Yilmaz, K. \& Tasdan, M. (2009). Organizational citizenship and organizational justice in Turkish primary schools. Journal of Educational Administration, 47(1), 108-126. 